\title{
HUBUNGAN ANTARA ATOPI DENGAN RIWAYAT PENYAKIT ALERGI DALAM KELUARGA DAN MANIFESTASI PENYAKIT ALERGI PADA BALITA
}

\author{
Endah Weninggalih, Cissy B Kartasasmita, Budi Setiabudiawan \\ Bagian IImu Kesehatan Anak Fakultas Kedokteran Universitas Padjadjaran/ \\ Rumah Sakit Hasan Sadikin, Bandung
}

\begin{abstract}
ABSTRAK
Prevalensii penyakit alergi cenderung meningkat dalam dekade terakhir. Hal ini disebabkan karena faktor genetik dan lingkungan. Faktor genetik dibuktikan dengan riwayat penyakit alergi dalam keluarga. Penyakit alergi merupakan gejala alergi pada individu yang atopi. Penelitian ini bertujuan untuk mengetahui apakah atopi dan riwayat penyakit alergi dalam keluarga merupakan faktor risiko timbulnya manifestasi penyakit alergi. Penelitian dilakukan di Puskesmas Garuda, Babakan Sari dan Padasuka Bandung selama bulan Februari-Maret 2007 dengan rancangan cross sectional. Subjek yang telah mempunyai data hasil uji tusuk kulit (UTK) dan ada tidaknya riwayat penyakit alergi dalam keluarga dilakukan pengisian kuesioner standar The International Study of Asthma and Allergies in Childhood (ISAAC) dan pemeriksaan fisis. Subjek dinyatakan atopi bila hasil UTK positif. Hubungan antara variabel dianalisis dengan metode Ki kuadrat dan rumus Mantel Haenszel untuk mengkontrol clonfounding variabel. Jumlah subjek sebanyak 260 anak (92\%), terdiri dari 130 anak dengan riwayat penyakit alergi dalam keluarga dan 130 anak tanpa riwayat penyakit alergi dalam keluarga. Berdasarkan UTK didapat 70 anak atopi dan 190 anak nonatopi. Manifestasi penyakit alergi terdapat pada 86 anak (33,08\%). Manifestasi terbanyak adalah rinitis alergika 41 anak (15,77\%), kemudian dermatitis atopik 18 anak (6,92\%), dan asma 5 anak (1,92\%). Kejadian manifestasi penyakit alergi terdapat pada $57,1 \%$ anak atopi dan $24,2 \%$ anak nonatopi. Kejadian manifestasi penyakit alergi terdapat pada $41,5 \%$ anak dengan riwayat penyakit alergi dalam keluarga dan $24,6 \%$ anak tanpa riwayat penyakit alergi dalam keluarga. Atopi mempunyai hubungan yang lebih kuat dengan manifestasi penyakit alergi pada balita, namun riwayat penyakit alergi dalam keluarga juga mempunyai hubungan sehingga merupakan hal yang penting untuk ditanyakan kepada orang tua.
\end{abstract}

Kata kunci: Manifestasi penyakit alergi, atopi, riwayat penyakit alergi dalam keluarga

\section{ASSOSIATION BETWEEN ATOPY WITH ALLERGIC HISTORY IN THE FAMILY AND ALLERGIC DISEASE IN UNDER FIVE YEAR OLD CHILDREN}

\begin{abstract}
There was an increase in prevalence of allergic diseases in the last decade. This was because of genetic and environmental factors. Genetic factor were proven by allergic history in the family. Allergic reaction in individu with atopy determined as allergic disease. The aim of this study was to know whether atopy and family allergic disease were risk factors for the occurrence of allergic disease manifestation. This study was conducted at Garuda, Padasuka and Babakan Sari Primary Health Center in Bandung, Indonesia, during February-March 2007, with cross sectional designed. Subjects with skin prick test (SPT) result and history or no history allergic disease data were questioned by The International Study of Asthma and Allergies in Childhood (ISAAC) and physical examination. Data were analyzed using chi square and Mantel Haenszel test for confounding variables. A total of $260(92 \%)$ children joined the third phase; consisted of 130 children with family history of allergic and 130 children without family history of allergic. Based of SPT consisted of 70 children with positive results and 190 children with negative results. The incidence of allergic disease was confirmed in $86(33.08 \%)$ children: $41(15.77 \%)$ children with allergic rhinitis, $18(6.92 \%)$ children with atopic dermatitis, and $5(1.92 \%)$ with asthma. Allergic diseases manifestation were confirmed in $57.1 \%$ atopy children and $24.2 \%$ nonatopy children. Allergic diseases manifestation were confirmed in $41.5 \%$ children with and $24.6 \%$ children without family history of allergic. Atopy has stronger association with allergic disease manifestation in under five children, but family history of allergic also has association so it's important to ask parents.
\end{abstract}

Key words: Allergic diseases manifestation, atopy, family history of allergic

\author{
Alamat Korespondensi: \\ Endah Weninggalih, dr. \\ Bagian IImu Kesehatan Anak Fakultas Kedokteran Universitas Padjadjaran/ \\ RS. Hasan Sadikin Bandung, \\ JI. Pasteur No.38 Bandung 40163 Indonesia, \\ Telp.022-2035957, email:erosmayudi@yahoo.com
}




\section{PENDAHULUAN}

Prevalensi penyakit alergi meningkat dalam dekade terakhir baik di negara maju maupun di negara berkembang. ${ }^{1}$ Peningkatan ini disebabkan karena faktor genetik dan lingkungan. ${ }^{2-4}$ Namun prevalensi di negara berkembang, termasuk Indonesia, lebih rendah dibandingkan dengan negara maju. ${ }^{1}$ Prevalensi yang lebih rendah di negara berkembang ini kemungkinan dipengaruhi faktor lingkungan. ${ }^{5}$ Faktor lingkungan yang mempengaruhi tersebut antara lain alergen, infeksi, ketegangan psikologis, dan gaya hidup. ${ }^{6}$ Beberapa penelitian membuktikan peningkatan paparan terhadap penyakit infeksius dan produk mikroba (endotoksin), berhubungan dengan gaya hidup yang "kurang bersih" pada komunitas negara berkembang dibandingkan negara maju, sehingga menyebabkan deviasi imun dari perkembangan sistem imun menjadi respons nonalergi. Hal ini disebut sebagai hygiene hypothesis. ${ }^{5,7}$ Faktor genetik dapat dibuktikan dengan riwayat penyakit alergi dalam keluarga. Seorang anak yang berasal dari keluarga dengan riwayat penyakit alergi akan berisiko mengalami penyakit alergi dua sampai tiga kali lebih tinggi dibandingkan dengan yang tidak punya riwayat penyakit alergi di keluarganya. ${ }^{6,8}$

Penyakit alergi seperti dermatitis atopik (DA), alergi makanan, asma, dan rinokonjungtivitis merupakan penyakit kronik yang paling sering terjadi pada anak. Penyakit ini merupakan gejala alergi pada individu yang atopi. Atopi adalah kecenderungan personal dan/atau familial, biasanya pada masa anak atau remaja, untuk tersensitasi dan menghasilkan IgE sebagai respons terhadap pajanan alergen, biasanya protein. Istilah atopi tidak dapat digunakan sebelum adanya bukti sensitisasi lgE yang ditandai dengan radio allergo sorbent testing (RAST) atau uji tusuk kulit (UTK) positif. ${ }^{9}$

Munculnya gejala pada usia tertentu yang berbeda-beda dari masing-masing penyakit alergi merupakan perjalanan alamiah penyakit yang disebut atopic march. Manifestasi penyakit alergi yang pertama kali timbul pada anak adalah DA yang dapat timbul sejak lahir, selanjutnya alergi makanan, kemudian diikuti asma, dan rinitis alergi. Seluruh manifestasi tersebut telah timbul pada lima tahun pertama kehidupan. ${ }^{10}$

Hingga saat ini belum ada penelitian di Indonesia yang menghubungkan atopi dan riwayat penyakit alergi dalam keluarga dengan manifestasi penyakit alergi pada anak bawah lima tahun (balita). Penelitian ini bertujuan untuk mengetahui apakah atopi dan riwayat penyakit alergi dalam keluarga merupakan faktor risiko timbulnya manifestasi penyakit alergi pada balita di Indonesia.

\section{METODE}

Penelitian komparatif observasional dengan rancangan cross sectional ini dilakukan bulan Februari hingga Maret 2007 di wilayah kerja Puskesmas Babakan Sari, Padasuka dan Garuda di kota Bandung. Data mengenai riwayat penyakit alergi dalam keluarga diambil dari kuesioner berdasarkan anamnesis dari orang tua. Ukuran sampel adalah seluruh anak yang telah dilakukan UTK yaitu sebanyak 284 anak, terdiri dari 80 anak dengan atopi dan 204 anak nonatopi. Subjek tidak ikut dalam penelitian bila pindah alamat. Penelitian dilakukan dengan cara anamnesis menggunakan kuesioner standar the International Study of Asthma and Allergies in Childhood (ISAAC) untuk alergi yang telah divalidasi guna melihat manifestasi penyakit alergi pada anak. ${ }^{11}$

Analisis statistik menggunakan uji $\mathrm{Ki}$ kuadrat yaitu untuk menguji hubungan variabel data kualitatif. Untuk menilai hubungan atopi dan manifestasi penyakit alergi pada balita, dengan confounding variabel riwayat penyakit alergi dalam keluarga digunakan rumus Mantel Haenszel. Penelitian ini telah mendapat persetujuan dari Komite Etik Penelitian Kesehatan Fakultas Kedokteran Universitas Padjadjaran/ RS Hasan Sadikin.

\section{HASIL}

Terdapat 260 anak (92\%) berusia antara 44-52 bulan yang mengikuti penelitian ini. Subjek terdiri dari 130 anak dengan dan 130 anak tanpa riwayat penyakit alergi dalam keluarga. Berdasarkan UTK didapat 70 anak atopi dan 190 anak nonatopi.

Berdasarkan kuesioner ISAAC didapatkan 86 dari 260 anak $(33,08 \%)$ mempunyai manifestasi penyakit alergi. Karakteristik jenis kelamin, usia, berat dan tinggi badan, serta status gizi antara anak dengan dan tanpa manifestasi penyakit alergi dapat dilihat pada Tabel 1.

Kejadian manifestasi penyakit alergi pada balita berdasarkan kuesioner ISAAC dapat dilihat pada Gambar.

Kejadian manifestasi penyakit alergi yang paling banyak pada penelitian ini yaitu rinitis alergika sebanyak 41 balita $(15,77 \%)$, kemudian dermatitis atopik sebanyak 18 balita $(6,92 \%)$, dermatitis atopik dan rinitis alergika sebanyak 12 balita (4,62\%), asma sebanyak lima balita $(1,92 \%)$, asma dan rinitis alergika sebanyak lima balita $(1,92 \%)$, dermatitis atopik, asma, dan rinitis alergika sebanyak empat balita $(1,54 \%)$, serta dermatitis atopik dan asthma pada satu orang balita $(0,38 \%)$.

Kejadian manifestasi penyakit alergi pada balita terjadi baik pada kelompok balita 
atopi maupun nonatopi. Analisis statistik kejadian manifestasi penyakit alergi pada balita berdasarkan atopi dan nonatopi dapat dilihat pada Tabel 2.

Dari Tabel 2 terlihat bahwa kejadian asma $(p=0,076)$, dermatitis atopik $(p=0,022)$, rinitis alergika $(p=0,000)$, dan seluruh manifestasi penyakit alergi $(p=0,000)$ berbeda bermakna antara balita atopi dan nonatopi.
Kejadian manifestasi penyakit alergi terjadi baik pada balita dengan maupun tanpa riwayat penyakit alergi dalam keluarga. Analisis statistik kejadian manifestasi penyakit alergi pada balita berdasarkan riwayat penyakit alergi dalam keluarga dapat dilihat pada Tabel 3.

Dari Tabel 3 terlihat bahwa kejadian asma $(p=0,003)$, rinitis alergika $(p=0,020)$, dan seluruh manifestasi penyakit alergi $(p=0,004)$

Tabel 1 Karakteristik Subjek Berdasarkan Manifestasi Penyakit Alergi

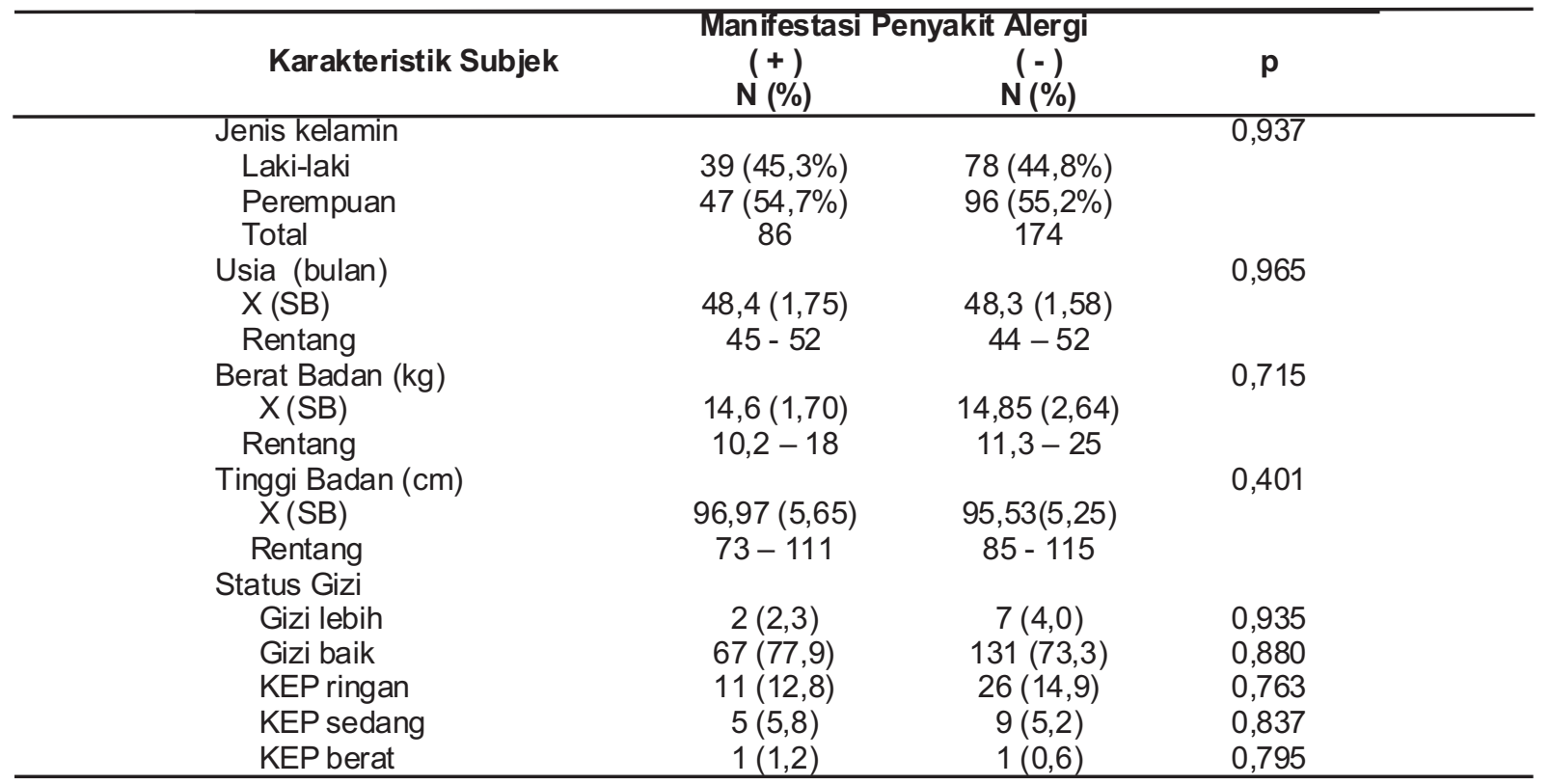

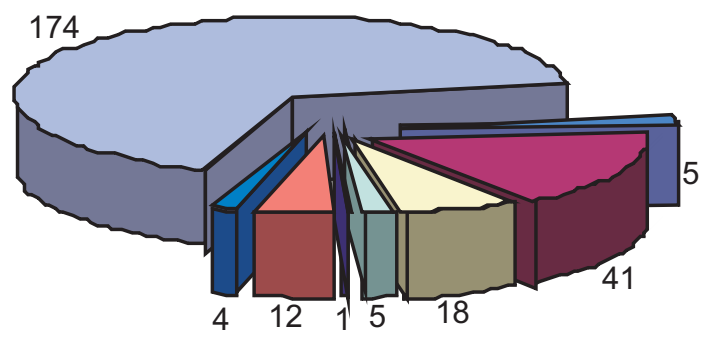

Asma ( 5)

$\square$ Rinitis Alergika/RA (41)

$\square$ Dermatitis Atopik/DA (18)

$\square$ Asma+RA (5)

Asma+DA (1)

$\square \mathrm{DA}+\mathrm{RA}(12)$

Asma+DA+RA (4)

$\square$ Tidak ada Penyakit Alergi (174)

Gambar Kejadian Manifestasi Penyakit Alergi pada Balita

Tabel 2 Kejadian Manifestasi Penyakit Alergi pada Balita Berdasarkan Atopi dan Nonatopi

\begin{tabular}{|c|c|c|c|c|c|}
\hline $\begin{array}{c}\text { Manifestasi Penyakit Alergi pada } \\
\text { Balita }\end{array}$ & & $\begin{array}{r}\text { opi } \\
\%\end{array}$ & $\begin{array}{c}\text { Non } \\
\mathbf{N}\end{array}$ & $\begin{array}{c}\text { atopi } \\
\%\end{array}$ & Kemaknaan \\
\hline \multicolumn{6}{|l|}{ Asma } \\
\hline$(+)$ & 7 & 10 & & 4,2 & $x 2=3,154$ \\
\hline$(-)^{\prime}$ & 63 & 90 & 182 & 95,8 & $p=0,076^{*}$ \\
\hline \multicolumn{6}{|l|}{ Dermatitis atopik } \\
\hline$(+)$ & 15 & 21,4 & 20 & 10,5 & $x^{2}=5,21$ \\
\hline$(-)$ & 55 & 78,6 & 170 & 89,5 & $\ddot{p}=0,022^{*}$ \\
\hline \multicolumn{6}{|l|}{ Rinitis Alergika } \\
\hline$(+)$ & 30 & 42,9 & 32 & 16,8 & $x 2=19,064$ \\
\hline$(-)$ & 40 & 57,1 & 158 & 83,2 & $p=0,000^{*}$ \\
\hline \multicolumn{6}{|l|}{ Penyakit Alergi } \\
\hline$(+)$ & 40 & 57,1 & 46 & 24,2 & $x^{2}=25,062$ \\
\hline$(-)$ & 30 & 42,9 & 144 & 75,8 & $p=0,000^{*}$ \\
\hline
\end{tabular}


Tabel 3 Kejadian Manifestasi Penyakit Alergi pada Balita Berdasarkan Riwayat Penyakit Alergi dalam Keluarga

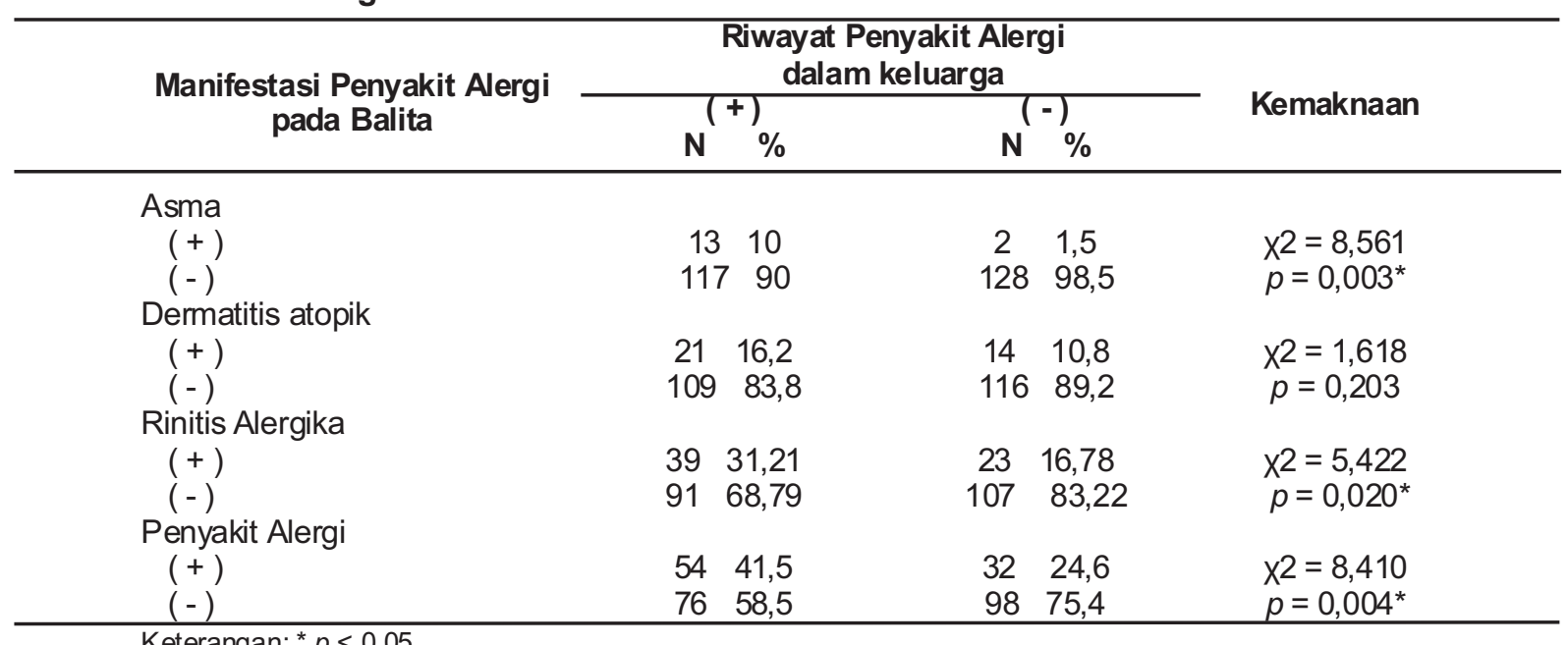

Keterangan: ${ }^{*} p<0,05$

Tabel 4 Kejadian Manifestasi Penyakit Alergi Berdasarkan Riwayat Penyakit Alergi dalam Keluarga dan Atopi

\begin{tabular}{cllcc}
\hline $\begin{array}{c}\text { Riwayat } \\
\text { Penyakit Alergi } \\
\text { dalam Keluarga }\end{array}$ & Atopi/ & \multicolumn{2}{c}{ Penyakit Alergi } & RR (95\% Cl) \\
\hline$(+)$ & Atopi & 28 & 12 & $3,50(2,25-5,44)$ \\
& Nonatopi & 26 & 64 & $1,44(0,87-2,40)$ \\
$(-)$ & Atopi & 12 & 18 & $2,00(1,11-3,60)$ \\
& Nonatopi & 20 & 80 & 1,0 \\
\hline
\end{tabular}

berbeda bermakna antara balita dengan dan tanpa riwayat penyakit alergi dalam keluarga, sedangkan pada kejadian dermatitis atopik tidak terdapat perbedaan yang bermakna secara statistik $(p=0,203)$.

Kejadian manifestasi penyakit alergi pada balita terdapat pada balita dengan dan tanpa riwayat penyakit alergi dalam keluarga, kemudian dihubungkan berdasarkan atopi dan nonatopi. Analisis statistik kejadian manifestasi penyakit alergi pada balita berdasarkan riwayat penyakit alergi dalam keluarga dan atopi dapat dilihat pada Tabel 4 .

Pada Tabel 4 terlihat bahwa kejadian manifestasi penyakit alergi pada balita atopi dengan riwayat penyakit alergi dalam keluarga berbeda secara bermakna bila dibandingkan dengan anak nonatopi yang tidak mempunyai riwayat penyakit alergi dalam keluarga.

Dengan rumus Mantel-Hanszel didapat $X 2=21,66$, dengan nilai $p<0,001 ; R R=2,36$; $95 \%$ IK: 1,64-3,13. Hal ini berarti terdapat hubungan antara atopi dan timbulnya manifestasi penyakit alergi pada balita, dengan confounding variable riwayat penyakit alergi dalam keluarga.

\section{PEMBAHASAN}

Jumlah subjek yang mengikuti penelitian ini ada
260 balita. Pada penelitian ini terdapat 86 (33\%) balita yang mempunyai manifestasi penyakit alergi. Karakteristik jenis kelamin, usia, berat badan, dan tinggi badan balita serta status gizi antara balita dengan dan tanpa manifestasi penyakit alergi tidak terdapat perbedaan yang bermakna $(p>0,05)$. Penelitian yang dilakukan Hafsah $^{12}$ pada tahun 2005 mendapatkan kejadian penyakit alergi lebih banyak terjadi pada anak laki-laki (53\%). Penelitian lain di Inggris juga menunjukkan bahwa anak laki-laki mempunyai risiko lebih tinggi untuk mempunyai DA. ${ }^{13}$ Hubungan antara jenis kelamin dan asma bervariasi sesuai usia. Pada masa awal anakanak, kejadian asma lebih sering terjadi pada anak laki-laki, namun pada usia lebih tua kejadian asma seimbang antara anak laki-laki dan perempuan. ${ }^{14}$

Manifestasi penyakit alergi terbanyak pada penelitian ini adalah rinitis alergika yaitu sebanyak $41(15,77 \%)$ balita, kemudian diikuti DA sebanyak $18(6,92 \%)$ balita, dan asma sebanyak lima $(1,92 \%)$ balita. Hal ini berbeda dengan penelitian di Australia yaitu pada usia 6-7 tahun terdapat penyakit asma sebanyak $27 \%$, DA sebanyak $23 \%$, dan rinitis alergika $18 \%$. $^{15}$ Hasil yang berbeda ini diduga karena adanya perbedaan lingkungan dan usia subjek.

Hasil penelitian ini mendapatkan kejadian rinitis alergika lebih tinggi daripada DA, hal ini tidak sesuai dengan atopic march yang 
menyatakan rinitis alergika biasanya meningkat setelah usia lima tahun. ${ }^{10}$ Penyebabnya karena pada penelitian ini hanya menggunakan kuesioner berdasarkan anamnesis dari orang tua. Saat penelitian tidak ditemukan kasus rinitis alergika secara klinis, maka mungkin ada estimasi yang salah.

Manifestasi penyakit alergi terdapat pada 40 dari $70(57,1 \%)$ anak atopi. Kejadian asma terjadi pada 15 anak, sebanyak $47 \%$ (tujuh anak) di antaranya adalah atopi. Hal ini serupa dengan penelitian di Kenya, kejadian asma terjadi pada $40 \%$ subjek dengan hasil UTK positif (atopi). ${ }^{2}$ Penelitian lain menunjukkan hasil UTK positif terhadap aeroallergen berhubungan dengan peningkatan risiko terjadinya wheezing. ${ }^{14}$

Manifestasi penyakit alergi pada penelitian ini terdapat pada 54 dari $130(41,5 \%)$ anak dengan riwayat penyakit alergi dalam keluarga dan 32 dari $130(24,6 \%)$ anak tanpa riwayat penyakit alergi dalam keluarga, perbedaan ini bermakna secara statistik $(p=0,004)$. Hasil penelitian yang dilakukan oleh Koning et $a f^{\beta}$ menyebutkan bahwa bila salah satu orangtua memiliki penyakit alergi maka anak mempunyai risiko $20-40 \%$ menderita penyakit alergi. Apabila kedua orangtuanya memiliki penyakit alergi maka risiko menjadi $60-80 \%$, apabila saudara kandung memiliki penyakit alergi maka anak mempunyai risiko $20-30 \%$. Sedangkan bila orangtua tidak memiliki penyakit alergi maka risiko anak menderita penyakit penyakit alergi sebesar $10 \%$. Namun pada penelitian ini tidak diperinci anggota keluarga yang memiliki riwayat penyakit alergi.

Kelemahan penelitian ini antara lain ini adalah kriteria diagnosis manifestasi penyakit alergi yang ditegakkan berdasarakan kuesioner ISAAC. Saat penelitian peneliti tidak mendapatkan kasus penyakit alergi secara klinis sehingga ada kemungkinan estimasi yang salah terhadap penyakit alergi. Kemungkinan ini dapat dikurangi dengan memanfaatkan gambar manifestasi penyakit alergi saat wawancara. Kelemahan lain adalah timbulnya kasus baru penyakit alergi dapat lebih banyak ditemukan pada anak lebih besar karena secara klinis onset penyakit dapat terjadi pada usia yang berbeda-beda. ${ }^{10,16}$ Penelitian ini mengambil subjek usia bawah lima tahun sehingga diharapkan temuan diagnosis penyakit alergi juga akan lebih banyak terjadi mengingat terdapatnya atopic march. Berdasarkan atopic march penyakit alergi dengan prevalensi tertinggi pada usia lima tahun adalah DA dan yang terendah adalah rinitis alergika. ${ }^{10}$ Selain itu terdapat kelemahan data tentang riwayat penyakit alergi dalam keluarga pada penelitian ini mungkin kurang akurat karena ditegakkan hanya berdasarkan anamnesis tanpa disertai pemeriksaan penunjang, misalnya kadar IgE total dan IgE spesifik atau UTK pada anggota keluarga yang diduga menderita penyakit alergi.

Kesimpulan penelitian ini adalah atopi mempunyai hubungan yang lebih kuat dengan manifestasi penyakit alergi pada balita, namun riwayat penyakit alergi dalam keluarga juga mempunyai hubungan sehingga merupakan hal yang penting untuk ditanyakan kepada orangtua.

\section{DAFTAR PUSTAKA}

1. The International Study of Asthma and Allergies in Childhood (ISAAC) Steering Committee. Worldwide variation in prevalence of symptoms of asthma, allergic rhinoconjuctivitis, and atopic eczema: ISAAC. Lancet. 1998;351:1225-32.

2. Weinberg EG. Urbanization and childhood asthma in South Africa. ACl International. 2000;suppl I:39-42.

3. Yadav M. Maternal factors in atopy. Medical Progress. 2000;27:15-22.

4. Kay AB. Allergy and allergic diseases. N Eng J Med. 2001;344:30-7.

5. Gold MS, Kemp AS. Atopic disease in childhood. MJA. 2005;182:298-304.

6. Koning $\mathrm{H}$, Baert MRM, Oranje AP, Savelkoul HFJ, Neijems HJ. Development of immune factors, related to allergic mechanisms, in young children. Dalam: Koning $\mathrm{H}$, penyunting. $\mathrm{T}$ and $\mathrm{B}$ cell activation in childhood allergy. Rotterdam: Pubmed; 2000. hlm. 11-41.

7. Romagnani S. Allergy: is it a TH2-predominant disease? Pro. Dalam: Isolauri E, Walker WA, penyunting. Allergic diseases and the environment. Switzerland: Karger; 2004. hlm. 69-95.

8. Kjellman NIM. Prediction and prevention of atopic allergy. Dalam: Hamsten MVH, Wickman $\mathrm{M}$, penyunting. 30 years with $\lg \mathrm{E}$. Copenhagen: Munksgaard; 2000. hlm. 73-7.

9. Johansson SGO, Bieber T, Dahl R, Friedmann $\mathrm{PS}$, Lanier $\mathrm{BQ}$, Locley RF, et al. Revised nomenclature for allergy for global use: report of the nomenclature review committee of the world allergy organization, October 2003. J Allergy Clin Immunol. 2004;113:832-6.

10. Barnetson RSC, Rogers M. Childhood atopic eczema. BMJ. 2002;324:1376-9.

11. Asher MI, Keil U, Anderson HR, Beasley R, Crane J, Martinez F, et al. International Study of Asthma and Allergies in Childhood (ISAAC): rationale and methods. Eur Resp J. 1995;8:483-91.

12. Hafsah T. Hubungan antara kejadian penyakit atopik pada anak dan status IgE tali pusat saat lahir serta riwayat penyakit atopik dalam 
keluarga. Tesis. Bandung: Fakultas Kedokteran Universitas Padjadjaran; 2005.

13. Morgan J, Williams P, Norris F, Williams CM, Larkin M, Hampton S. Eczema and early solid feeding in preterm infants. Arch Dis Child. 2004;89:309-14.

14. Asher MI, Grant C. Epidemiology of asthma. Dalam: Chernick V, Boat TF, Wilmott RW, Bush
A, penyunting. Disorders of the respiratory tract in children. Edisi ke-7. Philadelphia: Saunders; 2006. h. 762-85.

15. Gold MS, Kemp AS. Atopic disease in childhood. MJA. 2005;182:298-304.

16. Kristal L, Klein PA. Atopic dermatitis in infants and children. An update. Pediatri Clin North Am. 2000;47:877-95. 